\title{
ЖЕНСКОТО ПИСМО НА ОВИДИЈ ШТО НЕДОСТАСУВА ВО ТРАГЕДИЈАТА НА ЕВРИПИД
}

\section{Крайка содржина}

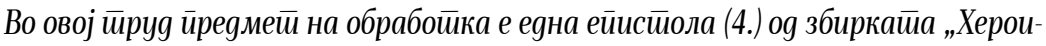

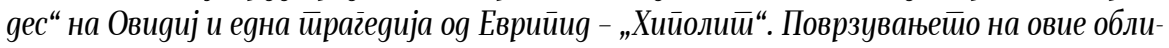

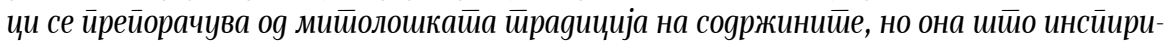

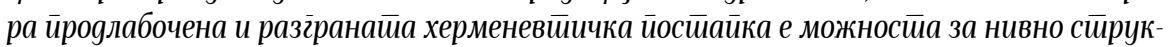
йурно йоврзување и иррейлейување во еgинсиивен книжевен облик. Имено, независно

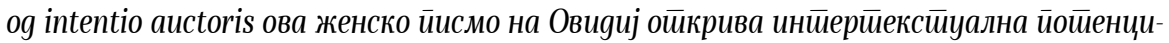

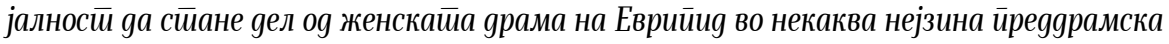

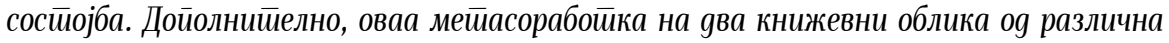

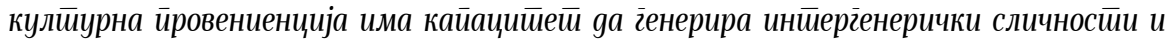

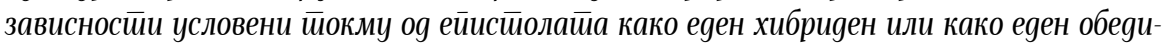
нувачки жанр.

Клучни зборови: ЖЕНСКО ПИСМО, ЛИРСКО ПИСМО, „ХЕРОИДЕС“, ОВИДИЈ, „ХИПОЛИТ“, ЕВРИПИД

Женското писмо на Овидиј, за кое станува збор во овој труд, е дел од збирката Хероиgес ${ }^{1}$ (Хероини). Оваа збирка може да се контекстуализира на разни начини и во различни области, книжевни и некнижевни, почнувајќи од оние кои се однесуваат на самиот автор, но и оние кои се надвор од неговиот личен опус, надвор од

\footnotetext{
${ }^{1}$ Првото издание на оваа збирка составувано во исто време со збирката Amores (о. 15 г. ст. е.) содржело песни-писма од женски митолошки ликови упатени до нивните љубовници или сопрузи. Соодветно на митолошката провениенција на епистоларните субјекти, во чие друштво се сретнува и Сапфа очигледно поради фантазмагоричноста на нејзиниот адресат Фаон и нивната митологизирана љубов, ова издание било насловено Heroides (Хероини) со една препознатлива грчка форма за женски род по аналогија на првичната форма за машки род

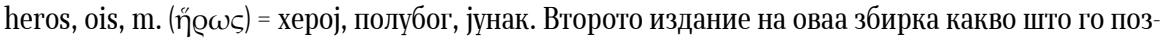
нава традицијата на текстовите од Овидиј е дополнето со уште неколку епистоларни песниодговори на адресираните херои (Парис gо Елена, Леандар gо Хероја и Аконӣuј gо Киgийа) со што збирката, покрај петнаесетте еднонасочни епистоларни обраќања, добила и три епистоларни комуникации. Оттаму првичниот наслов на збирката како несоодветен и неточен (бидејќи епистоларните субјекти не се само хероини, туку има и херои) бил променет во Epistulae (Писма) како што ги нарекува самиот Овидиј (Ars amat. 3.345).
} 
неговото поле на дејствување, надвор од историското време и простор. Во поетиката на Овидиј збирката елегии Хероиgес има позиција на фокус во кој се обединуваат други негови книжевни производи со различна жанровска провениенција, а со тоа и со разновидни капацитети за контекстуализација. Оттаму, песните на оваа збирка поради Љубовта како основен книжевен мотив се во тематско сродство со збир-

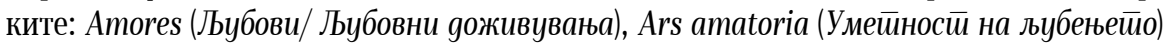
и Remedia amoris (Лекови og љубовйа); поради митолошката рамка во која се обработува книжевната материја, збирката Хероини е реално екстернализиран дел од епската митопоетика Мейаморфози (Преобразбu); ${ }^{2}$ поради книжевениот облик, овие љубовни писма заедно со Epistulae ex Ponto (Писма og Понйос / Црно Море) го сочинуваат епистоларниот книжевен корпус на Овидиј, а поради нагласената родова хомогенизација на епистоларниот субјект, овие женски писма и йисма (женски guскурс) книжевно се солидаризираат со изолираната и, најверојатно, недовршена долга песна Medicamina Faciei Feтіпеае (Прейарайи за женскойо лице). ${ }^{3}$ Книжевните релации на збирката Хероиgес со другите книжевни производи од опусот на Овидиј ги мапираат контекстуалните области каде што можат да се сместат херменевтичките

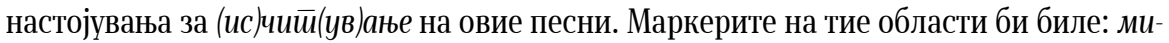

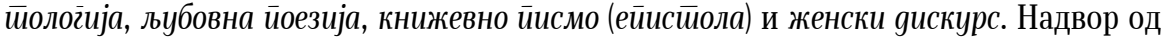
книжевното дејствување на Овидиј, надвор од римскиот книжевен и күлтурен круг, со истите маркери може да се означат контекстите на некои Еврипидови драми, во

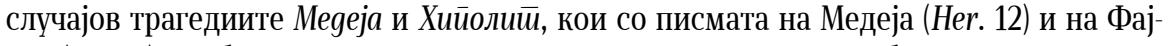
дра (Her. 4) од збирката Хероиgес градат метарелации на протообрасци за семантички и формативни структури.

1.

Овидиј во 2 г. ст. е. во својата дидактичка збирка Ars amatoria (3.345-6) ${ }^{4}$ тврди дека неговите претходно објавени Писма (sc. Хероиgес) се „дело какво што (дотогаш) не било познато за другите“ римски поети. Ваквата квалификација за по-

\footnotetext{
${ }^{2}$ Спореди Хероиgес 12 (Меgеја gо Јасон) и Мейаморфози 7.1-424.

${ }^{3}$ Оваа песна претставува извесен книжевен активизам на Овидиј со кој го остварува својот објавен проект (Ars amat. 3.101-128) за сеопфатно славење и спроведување на Негата (Cultus) во насока на целосна урбанизација на Рим и негово конечно ослободување од вековната зависност од вредносниот маркер на „големо село“. Спореди Хоратиј, Писма 2.1.156-7: Graecia capta ferum victorem cepit et artis|intulit agresti Latio (Освоената Хелада го освои својот жесток освојувач и уметностите ги внесе во селскиот Латиј).

${ }^{4}$ Во овие елегии Овидиј им се обраќа на мажите (1. и 2. книга) и на жените (3. книга) и ги упатува во вештината на љубење, покрај другото, и со препораки за внимателно одбрана лектира. Освен делата на Калимах, Сапфа, Тибул, Менандар инструктивни за унапредување на љубовните стратегии според Поетот, секако, се и неговите збирки Amores и Epistola за кои советува да бидат читани „тивко и нежно... со дотерана дикција“ (docili molliter ore... composita voce) [Ars amat. 3.344-5].
} 
етската иновативност на љубовните писма на Хероинииее само делумно може да биде релевантна и под услов првенството да се однесува само на римската книжевност и исклучиво на љубовната поезија. Зашто, ниту писмото како комуникациски производ ниту епистолата како книжевен облик не била непозната за Рим, а үште помалку за Хелада. Кажано поинаку, Овидиј, книжевно позициониран во последни-

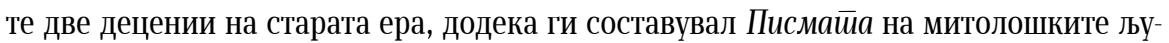
бовници можел да набљудува долговековна историја на хеленска и римска епистоларна традиција и како епистолографска пракса и како епистоларна книжевна форма.

Во лирската збирка Хероини можат да се забележат книжевни влијанија од различна културна и жанровска провениенција. Лирското писмо се сретнува инцидентно кај Лукилиј и кај Катул, а Хоратиј, повозрасниот современик на Овидиј, прв составил збирка од поетски писма и ја насловил Epistulae (Писма). Во книжевното писмо Хоратиј препознал способност за (по)блиска комүникација на авторот со својата публика ${ }^{5}$ и можност за послободна дистрибуција на сопствените ставови. Книжевното писмо ја презема и ја користи токму оваа особеност на писмото како комуникациска алатка во скриена форма достапна само до еден адресат, или до малкумина инволвирани во епистоларната комуникација, да објави содржина што се одликува со ексклузивност. Веројатно не е сосем случајно што писмото како медиум за дискурзивно општење стереотипно се поврзува со жената како епистоларен субјект поради неговата способност да го објави и воедно да го заштити личното, скриеното, внатрешното. ${ }^{6}$ Па така, родовата втемеленост на епистоларната типологизација според тематската доминанта резултира со констатација дека мажите пишуваат службени писма, за сериозни и општествено одговорни прашања, а жените пишуваат приватни писма. ${ }^{7}$ Токму „јавноста на приватноста“ е онаа особеност на писмото за која сведочи традицијата и го препорачува како соодветна книжевна форма во која Овидиј ќе ги осовремени митолошките љубовни приказни во согласност со оној Рим на кој со гордост самиот му припаѓa. ${ }^{8}$

Епистоларните дискурзивни стратегии директно произлегуваат од беседничката пракса и од реторската вештина и дидактика. Периодот во кој Овидиј е книжевно активен е период кој сведочи за исклучително богата епистоларна продукција евидентирана со бројни епистоларни збирки од различни епистоларни

\footnotetext{
${ }^{5}$ Види Taplin (ed.), p.122.

${ }^{6}$ Историјата на пишување писма започнува со женско писмо, она што го напишала персиската кралица Атоса. Види Rosenmeyer 2001, p. 25, 28, 49.

${ }^{7}$ Родово маркираната поларизација на просторот Дом-Град, Приватно-Јавно како ЖенскоМашко е влијателен модел на генерирање на најразлични општествени позиции и културни производи во антиката.

${ }^{8}$ Ars amat. 3.121-2: Prisca iuvent alios: ego me nunc denique natum|Gratulor: haec aetas moribus apta meis (На минатото нека му се радуваат други: јас си честитам себеси што токму сега сум роден: оваа доба со моите навики се совпаѓа).
} 
жанрови, книжевни и некнижевни, поетски и прозни. ${ }^{9}$ Популарноста на писмото како облик за книжевна провокација е најверојатно условена од растечкото влијание на реториката врз уметноста и особено од декламацијата како задолжителна фингирана беседа со која се совладувала и преку симулација се вежбала реторската вештина. Збирката лирски писма Хероиgес на многу рамништа ја објавува совладаната реторска вештина на Овидиј. Најнапред преку изборот на писмо епистоларниот субјект, во овој случај женски, што е радикално иновативна постапка за античката литература, да ја соопшти својата љубовна приказна и со тоа да активира една традиционална реторичка постапка на үंӨотои́ $\alpha$ (= поетика на карактерот, портретирање). ${ }^{10}$ Своето познавање на реторската вештина Овидиј го инвестира и во структурирањето на книжевното писмо како дискурзивен облик кој треба да ја оствари основната задача на секоја беседа, да изврши влијание и промена кај адресатот.

Покрај реториката, Писмайа на митолошките љубовници имаат своја книжевна етиологија и во традицијата на римската драма, поточно на Плаутовата комедија која во основа е преработка на хеленистичката нова атичка комедија, а оваа, пак, својата инспирација ја има во Еврипидовата трагедија. Во овие драми писмото не е самостоен книжевен облик, туку некаков драмски, поточно сценски реквизит, но со важна драматуршка задача и влијание врз драмското дејствие. Содржината на писмото најчесто не е дел од драмскиот текст, туку причина за драмско дејствување при што епистоларната комүникација, односно епистоларната рецепција генерира анаг̈норисис (препознавање). Љубовниие е йисма на Овидиј, чија содржина се одликува со драматичност, како самостојни поетолошки облици претставуваат на некој начин епистоларни драми, внатрешни дијалози ${ }^{11}$ на хероините со своите адресати пишувани во некој за нив вознемирувачки момент. Всушност, писмата ги пишуваат жени кои се обраќаат до отсутниот љубен (дали поради невозвратена љубов, или поради физичко отсуство, или, пак, поради напуштање на љубовната врска) со што се исполнува основниот конститутивен предуслов за епистоларна комуникација, ${ }^{12}$ а на епистоларната песна ѝ дава својство на книжевна убедливост.

\footnotetext{
${ }^{9}$ Види Novaković 1982.

${ }^{10}$ Спореди Sen. Contr. 2.2.12.1: Declamabat autem Naso raro controversias et non nisi ethicas; libentius dicebat suasorias: molesta illi erat omnis argumentatio (Назон (sc. Овидиј) ретко составуваше такви декламации во кои се расправаат етички прашања; со поголемо задоволство кажуваше беседи: докажувањето за сенешто му беше здодевно).

${ }^{11}$ Деметриј, За јазичниой израз 227: „Писмото исто како и дијалогот треба во најголема мера да го изразува карактерот, бидејќи секој кога пишува писмо го прави тоа речиси како да ја слика својата душа. Карактерот на авторот може да се согледа и од друг вид говор, ама ни од еден друг така како што може од писмо“.

12 Trapp, 1: „(...) потребата од писмо како посредник во комуникацијата разбирливо се појавува тогаш кога двете страни се физички далеку (одвоени) една од друга, па според тоа не се во можност непосредно да општат со употреба на глас или гест“.
} 
2.

Писмата на Медеја и на Фајдра од збирката Хероиgес од Овидиј на различни начини книжевно комуницираат со соодветните трагедии Хийолити и Меgеја од Еврипид. Писмойо на Фајgра многу едноставно може да се замисли како структурен елемент на трагедијата Хийолий бидејќи тоа е веќе присутно во драмскиот текст, но не како екстензивна епистоларна нарација, туку како епистоларен реквизит или таканаречено сценско писмо. ${ }^{13}$ На Овидиј несомнено му е позната оваа книжевна традиција и конкретната драмска ситуација за што можат да се препознаат бројни референци во епистолата на Фајдра. Кога речиси на самиот почеток епистоларниот субјект (Фајдра) му се обраќа на адресатот (Хиполит) и го наговара да го прочита писмото што има намера да го напише, го охрабрува да го направи тоа и покрај традицијата позната од трагедијата според која читањето писма може да биде и опасно, односно да убие. Ова укажување на ризичноста од епистоларната рецепција претставува своевидна фуснота во текстот на писмото на Овидиј која го поврзува со неговата сопствена протоисторија во еден друг книжевен текст, оној на Еврипидовата трагедија.

Кога Еврипид ја составувал својата трагедија Хийолий како основа ја користел приказната од митолошката традиција во која, разбирливо, нема епистола. Познато е дека Еврипид составил и прикажал две верзии на оваа драма. Во првата верзија Фајдра усно, на сцена му го соопштува својот копнеж на Хиполит. Оваа драма не била добро прифатена, публиката сметала дека ваквото експлицитно однесување на Фајдра ги надминува границите на вообичаената пристојност на жените. Во Уводот на античките изданија на втората верзија на трагедијата се објаснува дека Еврипид одново ја составил драмата за да ги отстрани оние содржини што биле навредливи за публиката во првата верзија. Па така, во втората верзија на оваа трагедија, онаа која е позната на традицијата, Фајдра се самоубива со што станува неможно својот љубовен копнеж да му го соопшти директно и усно на Хиполит. Но, заради потребите на драмското дејствие, било потребно да се најде книжевно средство со кое Фајдра ќе му ја соопшти на Тесеј причината за својата смрт и ќе го обвини за тоа Хиполит. Оттаму во втората верзија на драмата Еврипид го вклучува писмото, што ќе стане клучен драматуршки елемент. Писмата имаат способност да го направат присутен гласот на оној кој е отсутен и е автор на напишаното. Во овој случај, Фајдра преку писмото што го напишала останува да биде трајно присутна иако веќе трајно физички отсутна. Напишаните зборови, втиснати на плочките што висат обесени на нејзината мртва рака, се замена за живиот глас и, според природата на напишаното, тие му оставаат үште поголем впечаток на Тесеј отколку што би предизвикале усно искажаните обвинувања. Во услови кога авторот е трајно за-

\footnotetext{
${ }^{13}$ Rosenmeyer 2001, p.63: „Писмото како сценски реквизит се користи за да внесе живост на сцената, или за да биде визуелна поддршка на аргументот, или за да соопшти некоја деликатна информација. (...) Писмото е книжевна алатка со која се презентираат изминатите настани на сцена, но не преку чинот на дејствување, туку во наративен облик“.
} 
минат, напишаното има трајна вредност без можност за негова промена. Оттаму, Хиполит нема можност да каже нешто во своја одбрана со што ќе го убеди Тесеј во сопствената невиност. Тесеј не го чита писмото на глас, но со својата реакција ја известува публиката за неговата содржина, ${ }^{14}$ што ќе биде причина за трагичниот завршеток на драмата. Со писмото мртвата Фајдра си го заштитува угледот и едновремено обезбедува одмазда, а Тесеј го казнува синот со страшна смрт.

3.

Четири века по изведбата на трагедијата Хийолий во Атина, Овидиј во Рим го составува писмото на Фајдра до Хиполит како супститут на усно објавениот љубовен копнеж од првата верзија на Еврипидовата драма. Ова поетско писмо се издвојува од останатите епистоли во збирката Хероиgес по тоа што за разлика од сите други епистоларни субјекти кои се напуштени жени, Фајдра не е напуштена од својот љубовник, туку е во потрага по него. Таа го пишува своето љубовно писмо за да го освои својот адресат, односно да го убеди да ја прифати нејзината објавена љубов. На ваквата задача авторот на писмото, Овидиј, одговара со примена на соодветна реторска стратегија и активирање на стандардни постапки за влијание и промена на мислењето на адресатот.

Писмото на Фајдра има препознатлива структура на беседа форматирана според агендата за составување убедувачки дискурзивен облик. Фајдра го започнува писмото индиректно со дистанца и енигматично, себеси се претставува со трето лице и се нарекува gевојка og Крий (Cressa puella), а адресатот Хиполит го нарекува маж (роден) og Амазонка (Amazonius vir) и со тоа, освен потеклото, ја дефинира и посакуваната релација (vir - puella) заради што го пишува ова писмо. Во реторички контекст, Фајдра/Овидиј во увоgой (exordium) [1-6] ја мапира задачата на дискурзивното убедување во ова писмо. Очекувано следува раскажување (narratio) [7-16], делот во кој се изложуваат состојбите кои му претходат на чинот на убедување. Фајдра растајува дека долго се премислувала дали да ги открие своите чувства или да остане нема. Сепак, решила со писмо да проговори поттикната и охрабрена, убедена од силата на Љубовта (Amor), која овде е персонифицирана како многу моќно божество на чија сила не можат ни боговите да оддолеат, таа владее над сите и со сѐ. Фајдра му се обраќа директно на ова божество и го моли да помогне да го запали огнот во оној што е сега бесчувствителен. Во оваа инвокација на Амор може да се препознае традиционалното обраќање на Поетот до Муза кое во писмото на Фајдра треба да го отвори средишниот и најважен дел на убедувачкиот дискурс, а тоа е gокажу-

\footnotetext{
${ }^{14}$ Еврипид, Хийолит̄ 877-80:

О писна, писна писмото од несреќа!

Со ваков товар, каде? Умрев, пропаднав!

Јад каков, каков видов во пишаното;

што ечи, кутар јас!
} 
вање (argumentatio) [17-164]. Во овој случај Овидиј развива неколку аргументативни постапки втемелени во различните средства на убедување: оние кои се однесуваат

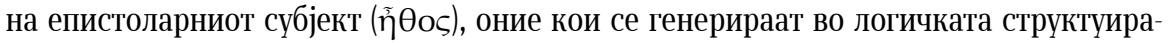
ност на дискурсот (

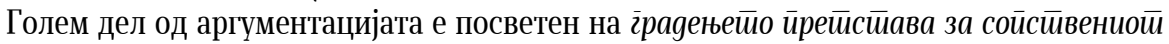

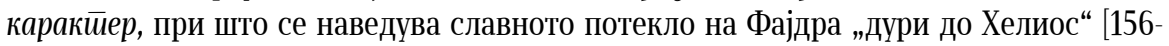
164]. Фајдра ја контекстуализира својата љубовна страст како „судбина на сопственото семејство“: нејзината баба Европа била заведена од Јупитер престорен во бик, нејзината мајка Пасифаја се вљубила во бикот испратен од Нептун и го родила чудовиштето Минотаур „нејзин грев и товар“, а нејзината сестра Аријадна му помогнала на туѓинецот Тесеј да го убие Минотаур и побегнала заедно со него. Во оваа низа „нестандардни љубовни искуства во семејството“ се вбројува и нејзината љубов кон Хиполит, што сега ја објавува [53-66]. Клучен дел од аргументацијата е обидот на Фајдра да ги објективизира околностите поврзани со Тесеј кои на некој начин ја препорачуваат оваа врска макар и на рамниште на сојузништво и одмазда. Таа потсетува дека Тесеј ги навредил и неа и својот син со тоа што ги напуштил и заминал кај својот пријател Пиритој; го обвинува и за убиството на Минотаур и за тоа што ја напуштил Аријадна и со тоа ја навредил неа, а со убиството на Амазонката Антиопа, мајката на Хиполит, го навредил и сопствениот син [105-128].

Во описот на љубовта на Фајдра може да се препознае ехо од Платоновиот Фајgар кога таа открива како љубовта кон Хиполит влијае на превоспитување на нејзиното однесување и поттикнува интерес за поинакви практики: да ја почитува Дијана повеќе од другите божества, да оди на лов, да вози колесница. Во својата исповед признава дека се чувствува како да е обземена од некакво божество, па се споредува со ентузијазираните придружнички на Бакхус и на Кибела [37-52].

Дел од аргументацијата се темели на стереотипната дихотомија на божиците Дијана и Венера, што е, инаку, основа врз која Еврипид ја структурира својата драма Хийолий. Фајдра препорачува нивно помирување во верската пракса на Хиполит и потсетува на неколку парадигми од митолошката традиција (Кефал, Адонис, Мелеагар) со што активира една од најмоќните алатки на убедувачкиот дискурс, йримерой [85-104].

Во завриниоё gел (conclusio) на писмото Фајдра му се обраќа директно на Хиполит и бара од него „да си го отвори срцето“ и да не биде „пожесток од дивиот бик што нејзината мајка Пасифаја го совладала“ [165-176]. Со молитва ја слави Венера, но и оние кои ги почитува Хиполит: Дијана, Фаун, Пан, Нимфите. Со последните стихови Фајдра се обидува да влијае на одлуката на Хиполит да одговори на нејзината љубов ${ }^{15}$ со активирање на највлијателното реторско средство за вакви

${ }^{15}$ Ovidius, Heroides 4. 175-6:

Addimus his precibus lacrimas quoque; verba precantis

qui legis, et lacrimas finge videre meas!

(додавам на овие молби уште и солзи; зборовите на оној што се моли ти ги читаш, и замисли како ги гледаш солзите мои.) 
случаи та́ $\theta$ оs, подигање на емоционалниот статус во насока соодветна со целта на убедувањето [165-176].

4.

Ако се занемарат историските рамки на книжевна продукција на Еврипи-

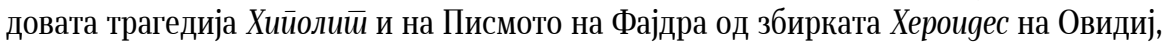
овие два поетски облика би можеле да се сретнат во заедничко дело на некое мета рамниште. Ова здружување би било оправдано од можноста да се исполни една пукнатина во текстот на драмата која зјае со енигматичноста на необјавената содржина на „немото писмо“. Писмото на Фајдра, како и останатите еднонасочни писма од збирката Хероugec претставуваат исповеди и наликуваат на фрагменти од инти-

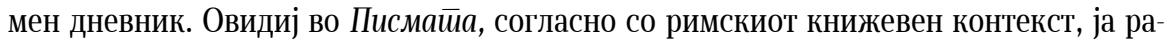
дикализира намерата на Еврипид ликовите (во драмата) да ги објавуваат личните и интимни искуства, па го одбира писмото како формат кој по дефиниција е наменет за другиот, за екстернализација и за објективизација на личното, на интимното. Екстензивноста на писмото и наратолошкиот карактер прават соодветна замена за стандардните сцени со гласникот во драмите кои имаат функција да објават содржини од зад сцената, од внатрешноста на домот, или храмот, од оние простори кои ѝ се недостапни на публиката за набљудување. 


\section{Литература}

Fulkerson, Laurel. (2005). The Ovidian Heroine as Author, Reading, Writing and Community in the Heroides. Cambridge: Cambridge University Press.

Lindheim, Sara H. (2003). Male and Female, Epistolary Narrative and Desire in Ovid's Heroides. The University of Wisconsin Press.

Novaković, Darko. (1982). "Fabularni oblici u antičkoj epistolografiji". Latina et Graeca 20, pp. 69-85.

Rosenmeyer, Patricia A. (2001). Ancient Epistolary Fictions. Cambridge: Cambridge University Press.

Rosenmeyer, Patricia A. (2006). Ancient Greek Literary Letters. London and New York: Routledge.

Taplin, Oliver, ed. (2000). Literature in the Roman World. Oxford: Oxford University Press.

Trapp, Michael, ed. (2003). Greek and Latin Letters, An Anthology with Translation. Cambridge: Cambridge University Press. 